\title{
A Practical Application of Appraisal Theory on Critical Reading in College English Teaching
}

\author{
WANG Ruo-mei \\ Jiangsu Business Institute, Nanjing, China
}

\begin{abstract}
Appraisal Theory is a new expansion theory in the linguistics field, which can provide theoretical supports for the college English teaching and help learners have a better analysis and understanding of discourses. Critical reading can effectively stimulate and cultivate learners' abilities of thinking and reflectone. The teaching of the critical reading, based on Appraisal Theory, has played a positive role in promoting students' reading level and linguistic application capacity. The concepts of Attitude, Engagement, and Graduation in Appraisal Theory are applied on reading teaching to realize the critical judgment and identification to author's value affect, writing positioning, and creative purpose. The critical reading by Appraisal systems is helpful in promoting students' language competence and enhancing the quality of readig comprehension. The teaching research illustrates the critical reading in Appraisal Theory is a new exploration in college English reading teaching and that the application of Appraisal Theory can surely add lots of depth and connotation to the critical reading.
\end{abstract}

Keywords: critical reading, Appraisal Theory, English teaching

\section{Introduction}

In the second language acquisition, reading has always been in an important position in language teaching and learning because it is both an essential learning ability and an effective way to obtain knowledge and information. Reading ability largely determines not only the amount of information one gets, but also the quality of understanding information as well. The reading skill is highly valued in English learning and as a result, the reading teaching has always attracted more attention from teachers and students. The critical reading is a higher reading level, which can enlighten reflective thinking and critical recognition. The critical reading is beyond traditional literal decoding and meaning interpretation and significantly encourages learners to promote the basic abilities of critical thinking and aesthetic appreciation and thus highlights reading competency.

Appraisal Theory is a new expansion theory in the linguistics field. It can provide theoretical supports for the college English teaching and help the learners have a better analysis and understanding of discourses. The theory is conductive in improving the quality of critical reading teaching and is beneficial for the reformation and innovation of the English teaching.

WANG Ruo-mei, associate professor, master, Foreign Languages Department, Jiangsu Business Institute. 


\section{Appraisal Theory Framework}

Appraisal Theory, derived from Systemic Functional Linguistics, was put forward by a group of researchers led by Professor James Martin of the Linguistics Department AT University of Sydney in the 1900s. Appraisal Theory is recognized as a particular approach to evaluate language, adopt stances, construct textual characters, and constitute interpersonal positioning and relationships (Martin \& White, 2005). It probes how speakers/writers pass their attitudes, judgments, or opinions on listeners/readers to form alliances with those who have the same experience and view and distance themselves from those who do not. Martin (2000) once stressed that Appraisal also explores how attitudes, judgments, and emotional responses from speakers/writers are explicitly presented or expressed implicitly in texts. Appraisal Theory is performed to analyze the discourse resources to negotiate the social relationships by telling listeners/readers how they feel about relevant persons or things.

Three categories are classified in Appraisal Theory: Attitude, Engagement, and Graduation, among which Attitude is subdivided into Affect, Judgment, and Appreciation, Engagement into Monogloss and Hetergloss, and Graduation into Force and Focus. As shown in Figure 1.

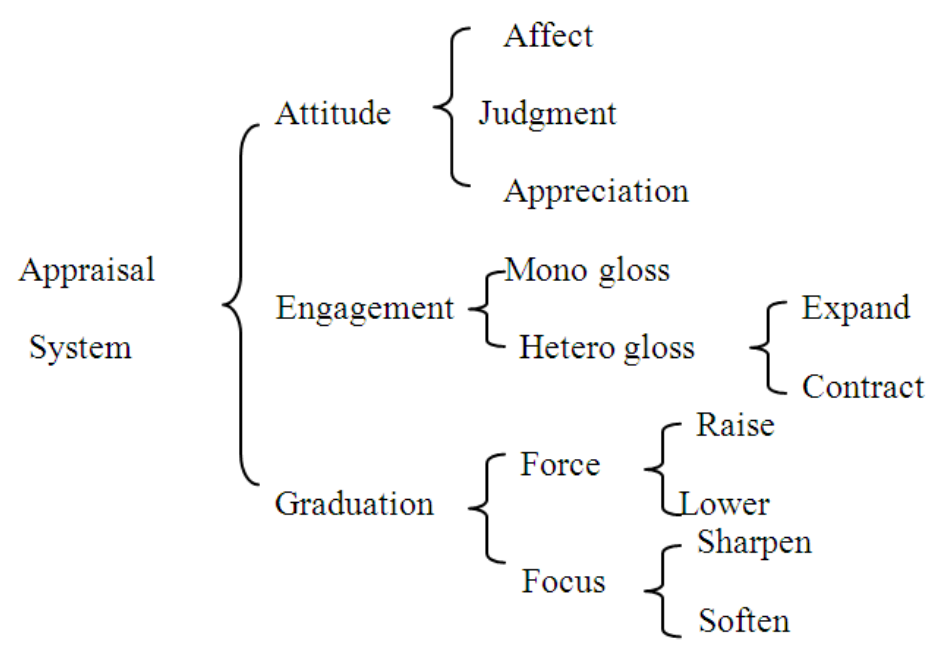

Figure 1. Appraisal system.

Attitude mainly refers to the values by reference either to emotional responses or to culturally-determined evaluating value systems (Martin \& White, 2005). Attitude is conveyed by means of Affect, Judgment, and Appreciation. Affect is a kind of emotional reflection or response based on behavior, text, and phenomenon. Affect can be expressed explicitly with positive or negative sense of emotion in words, such as love/hate, happy/sad, joy/despair, worried/confident, etc. It can also be expressed implicitly as an indirect sign of emotion. Judgment refers to attitudinal evaluation in which individual behavior is judged positively or negatively according to social norms and social constrains. Appreciation is an appreciative evaluation for the aesthetic characters on the text, process, or phenomenon, mainly for an inanimate object, rather than the behavior of people. The following three sentences can exhibit the characteristics of Affect, Judgment, and Appreciation:

(1) I feel happy about their coming. (Emotional response)

(2) It was silly of them to do that. (Judgment evaluation)

(3) It was an honest business. (Identifying appreciation) 
Engagement refers to the way of evaluators participating in discourse, in which language users adopt intervention techniques to regulate the responsibility and obligations of discourse resources. Monogloss and Heterogloss are subsystems of Engagement. Monogloss shuts down all the negotiations from other sounds or dialogue space while Heterogloss creates a wide range of sound consultation coexistence in space through the voice of project implementation. They are different styles and strategies in dealing with discourse resources. The sentence "The young man has been selfish." belongs to Monoglossic technique and "There is a different viewpoint though the young man has been described to be selfish." is illustrated in Heteroglossic one. Heterogloss is realized by Expansion and Contract. Expansion emphasizes the non-uniqueness of a voice and quotes other opinions and attitudes objectively to extend the dialogue space. Contract deliberately avoids or excludes other sounds and narrows or deprives of discourse right from external voices to get the effect of crunching dialogue space.

Graduation, the third dimension of Appraisal, is concerned with the values of scaling in terms of force and focus. Force can raise or lower the intensity of utterance and perform the function of turning the volume up or down. It has been labeled as intensifier or enhancer and expressed by such adverbials as slightly, rather, extremely, etc. Focus operates in terms of sharpness or softness of values. Values at the "sharp" end are exemplified by single word or by adding modifiers to words, like strongly, furthermore, tidy—very tidy, careful - the most careful. Values at the "soft" end are exemplified by such phrases as "to some extend, as good as" to carry out the charming of "vague language".

Based on Appraisal Theory, the interpersonal functions between linguistic subjects and linguistic receptors can be evaluated objectively to display fully the communicative significance and the language lifelikeness and nature. Applied in College English teaching, Appraisal Theory can surely provide theoretical and methodological guidance to help learners reach a higher reading level.

\section{Realization of Critical Reading}

\section{Basic Understanding of Critical Reading}

Reading is considered as an active activity in applied linguistics and psychology. Readers can predict, test, and confirm or negate information conveyed in a text on the basis of their experience, existent knowledge, and value systems. According to Mortimer and Charles (1972), there are four levels in reading: literal reading, inferential reading, critical reading, and appreciative reading. Critical reading and appreciative reading belong to the high-level reading, compared with the other two.

Critical reading is a creative and rational reading with the open mind - not to agree or disagree, but to discover. It involves understanding, questioning, and evaluating what the author is saying and forms own opinions or views. Paul (1995) said, critical reading often includes issues of critical thinking, which means it may be designed to improve abilities of analyzing materials, synthesizing findings, and proposing new ideas. With the aid of Appraisal systems, readers may experience the rationalities of the writer's positioning and catch the orientation of his/her emotional attitude as well as recognize the authenticity of information. To learners, the development of inferential, critical, and appreciative reading ability is actually of greater importance.

\section{Basic Elements of Critical Reading}

Critical reading includes the following five important elements: 
(1) Consider discourse background. Any article is written in a cultural context of a certain period which is often different from reader's. In the case, the differences between reader's values and attitudes and those represented by the author must be recognized and taken into account.

(2) Question assertions. Documents are scanned in question for tone, depth, and breadth. Before accepting and absorbing the information in them, be certain that author provides sufficient support for any assertions. Searching for facts, examples, and statistics that provide support is indispensable.

(3) Analyze assumptions. In many discourses, author's assumptions are implied and not directly stated. This means readers must read carefully in order to discover evidence, identify assumptions, and estimate their validity.

(4) Evaluate the sources. It is essential to evaluate that the sources the author quotes are credible, consistent, and relevant. At the same time, timeliness and current trend of the sources are also essential. Always check the sources before making a decision about whether or not they are reliable information.

(5) Identify author's attitude and bias. If the author is known to be emotionally or financially connected with the topic, be aware that the sources he/she uses may not fairly represent all views. Be careful of his/her linguistic resources and writing style that show affect, judgment, and appreciation.

\section{Teaching Appeal of Combination With Appraisal Theory and Critical Reading}

\section{Demands for Critical Reading in Appraisal Theory}

Critical reading in Appraisal systems contains two purposes: One is to understand the discourse; the other is to evaluate the discourse through Appraisal resources. According to Martin and White (2005), linguistic resources of Appraisal can help the writer/speaker express his/her attitudes, positions, and the covert values by utterances. The evaluation of discourse requires readers to have reflective thinking and critical cognition to reveal the interpersonal meanings of appraisal resources and highlight the importance of core appraisal resources in discourses.

The purpose of discourses is to inform, to persuade, to entertain, or some combination of the three. So the critical reading actually demands readers to catch useful information critically, make clear author's attitude and positions to certain events or phenomena in Appraisal systems and demonstrate author's affect, judgment, and appreciation in linguistics resources. The critical reading in Appraisal is helpful to instruct learners to develop the reflective thinking in reading teaching and have the critical acceptance to what has been learned so as to generate an advanced cultivation of linguistic competence.

\section{Excavation of Underlying Values and Ideology From a Critical Perspective}

Author's value systems shape his/her utterances in writing while his/her attitudinal positioning and dialogistic positioning can be figured out through his/her utterances. It is these utterances and positioning that make the author's internal values and underlying ideology explored and manifested completely.

Reading is an interaction process. The writer transfers language information and attempts to yield common linguistic space with readers. Readers remark and evaluate the information on the basis of their own value systems to have resonances or produce gaps in the subject. But in fact, it is not easy because author's underlying values and ideology are usually displayed implicitly in discourses and cannot be identified directly. The excavation of such values and ideology requires readers' thoughtful mind and insightful consciousness. With Appraisal systems, readers must have an analysis of utterance resources in discourse and figure out author's inner 
thought, true emotion, and specific culture. Readers also need to explore lexical chunks, sentences, and even paragraphs in discourse which can display author's affect, judgment, and appreciation to certain events or occasions. It is obvious that readers in critical reading techniques can establish linguistic alliance to make better interpersonal relationships with authors. Therefore, an important task in critical reading is to teach learners to be good at applying Appraisal systems in their reading and induce them to recognize accurately author's inner voice, joys, and sorrows and his/her value tendency as well.

\section{Illustration of Teaching Sample in Appraisal System}

\section{Integrated Analysis of Sample Text}

The sample text "There's a lot more to life than a job" is taken from Book 2 of New Horizon College English. It is a typical argumentative passage in which the author develops his concepts objectively and presents the supporting evidence logically and powerfully to convince readers of the soundness of his/her statement to the topic proposition-We ought to give our ability to our work, but our genius to our life. The author adopts different kinds of appraisal strategy to organize corpus paragraphs and express his/her internal voice about life and job so as to make readers have confidence in what he is saying and subscribe to his/her point of view naturally.

By Engagement and Graduation, the author conveys his/her resources in Affect, Judgment, and Appreciation more vividly and more distinctly and his/her persuasive techniques and argumentation intensity are also performed more prominently at the same time. Table 1 shows a collection of the most representative appraisal words and lexical chunks in the sample text. The table classifies the collection in the three parts: Attitude resources, Engagement resources, and Graduation resources. The application of Monogloss and Heterogloss in Engagement makes the discourse credible and authentic and under Graduation, Attitude values seem to have more power and strength than ever.

Table 1

Representative Appraisal Words and Lexical Chunks in Sample Text

\begin{tabular}{|l|l|l|l|}
\hline Name classification & Attitude resources & Engagement resources & Graduation resources \\
\hline Appraisal corpus & $\begin{array}{l}\text { Saddest, be proud of, frankly, at } \\
\text { a low, incredible, true, } \\
\text { short-sighted, conviction, the } \\
\text { most important, preferably, } \\
\text { prosperous, comfortable, } \\
\text { resources }\end{array}$ & $\begin{array}{l}\text { Reading a survey report..., on the other } \\
\text { hand, according to the survey based on } \\
\text { responses..., the survey revealed, it has } \\
\text { been remarked that.., beyond our } \\
\text { immediate needs, Oscar Wilde had it } \\
\text { right..., but..., many people..., it's a } \\
\text { fact..., I believe/think it can be, it is equally } \\
\text { true that..., we need to know..., Why can't } \\
\text { we..., We ought to... }\end{array}$ & $\begin{array}{l}\text { Truly, entirely, equally, } \\
\text { higher, more than ever, more } \\
\text { importantly, in the long run, } \\
\text { some, most }\end{array}$ \\
\hline
\end{tabular}

The illustration of sample text also refers to a statistical data analysis and artificial sampling inspection about Engagement resources, as shown in Table 2. Table 2 indicates Heterogloss is more than Monogloss and the frequency of Expansion is higher than that of Contract. The author utilizes such methods to form successfully a dialogue and consultation space to avoid too much subjective single voice in his/her statement. In the 800 -word text, the typical Heterogloss resources are used up to more than 15 times, such as "according to the survey based on responses..., Oscar Wilde had it right..., but...”, etc. The author's intention is to highlight his view, but not to 
exclude others' voices so as to create a communicative environment and achieve the goal of persuading the readers subjectively.

Table 2

Proportion Ratio of Engagement Resources

\begin{tabular}{|c|c|c|c|c|}
\hline \multirow{3}{*}{$\begin{array}{l}\text { Monogloss } \\
46.78 \%\end{array}$} & \multicolumn{4}{|c|}{$\begin{array}{c}\text { Heterogloss } \\
53.22 \% \\
\end{array}$} \\
\hline & \multicolumn{2}{|c|}{ Expansion } & \multicolumn{2}{|c|}{ Contract } \\
\hline & $\begin{array}{l}\text { Entertain } \\
12.23 \%\end{array}$ & $\begin{array}{l}\text { Attribute } \\
32.29 \%\end{array}$ & $\begin{array}{l}\text { Disclaim } \\
2.3 \%\end{array}$ & $\begin{array}{l}\text { Proclaim } \\
6.4 \%\end{array}$ \\
\hline
\end{tabular}

Decomposition Analysis of Sentence in Sample Text

The purpose of examining sentences in the sample text is to find out the evaluating resources and their individual roles or functions by Attitude subsystem. The sentence analysis by Affect, Judgment, and Appreciation can help understand author's natural attitude and creative positioning and reveal his values and moral tendency for the argumentation. The following of sentences selected in the sample text are in the order of the sequence they appear in the discourse.

Affect. Affect appraising resources in the sample text chiefly fall into three categories-Un/Happiness, In/Security, or Dis/Satisfaction. Typical sentences are extracted as follows:

(1) It has often been remarked that the saddest thing about youth is that it is wasted on the young. (Dissatisfaction) (Amplification)

(2) If only I knew then what I know now. (Dissatisfaction, Unhappiness)

(3) Not surprising in these hard times, the students' major objective "is to be financially well off". (Dissatisfaction, Insecurity)

(4) Less important than ever is developing a meaningful philosophy of life. (Dissatisfaction) (Amplification)

(5) "I'll tell them what they can do with their music, history, literature, etc." she was fond of saying. (Satisfaction, Happiness)

(6) Frankly, I'm proud of the young lady (not her attitude but her success). (Satisfaction, Happiness)

(7) Most people, in their youth, resent the Social Security deductions from their pay, yet a seemingly few short years later find themselves standing anxiously by the mailbox. (Insecurity, Dissatisfaction) (Amplification)

(8) It is equally true that our civilization has collected an incredible amount of knowledge in fields far removed from our own. (Satisfaction) (Amplification)

(9) It is equally true that, in studying the diverse wisdom of others, we learn how to think. (Satisfaction, Happiness)

Sentences (1), (2), (3), (4), and (7) express author's affect values of "Dissatisfaction" and "Insecurity" subjectively and objectively. Such expressions as "the saddest thing", "if only", "not surprising", and "less important" transfer readers some information that the young waste youth and fail to develop a meaningful philosophy of life. Phrase "to be financially well of" implies that the young are consumeristic and money-oriented and they really do not know there is more in life than a well-paid job. "To resent the Social Security deductions from their pay, to find themselves standing anxiously by the mailbox." in sentence (7) is obviously a negative affect expression, but has a little ironic at the same time. People are dissatisfied with "Social Security deductions" in their youth, but they themselves benefit from the deductions in retiring life. 
Phrases like "to be fond of", "to be proud of" in sentences (5) and (6) describe author's satisfactory affect toward the view of "more in life". Sentences (8) and (9) indicate that life is meaningful and full of an incredible amount of knowledge and diverse wisdom. With active, curious, and aggressive manners, life can bring happiness, satisfaction, and pleasure.

Judgment. Judgment appraising resources express author's positive or negative evaluation and statement for the theme "More in life than in job" under social norms and regulations.

(1) If it (whatever it may be) will not compute and you cannot drink it, smoke it, or spend it, then "it" holds little value. (negative capacity)

(2) Today's college beginners are "more consumeristic and less idealistic" than at any time in the 17 years of the poll. (negative capacity)

(3) Accordingly, today the most popular course is not literature or history but accounting. (negative capacity)

(4) Interest in teaching, social service, and the humanities is at a low, along with ethnic and women's studies. On the other hand, enrollment in business programs, engineering, and computer science is way up. (negative capacity)

(5) Can't we educate people for life as well as for c career? (positive capacity)

(6) Is it then not the duty of educational institutions to prepare the way for that revelation? (positive capacity)

(7) Most of us finally have the insight that quality of life is not entirely determined by a balance sheet. (positive capacity)

(8) Most people...finally arrive at the inevitable conclusion that they were meant to do more than serve a corporation, a government agency, or whatever. (positive capacity)

(9) More importantly, education teaches us to see the connections between things, as well as to see beyond our immediate needs. (positive capacity)

(10) But the most important argument for a broad education is that in studying the accumulated wisdom of the ages, we improve our moral sense. (positive capacity)

The judgmental evaluations can be put on a continuum with two extremes of the positive and negative. Sentences (1), (2), (3), and (4) are negative judgments to the young for their shortage of dialectical cognition to job and life. Expressions of "hold little values" and "more consumeristic and less idealistic" are author's negative evaluations to the young people's incorrect life values and "is at a low" and "is way up" tell a huge contrast in their major choice, with higher enrollment in business programs, engineering, and compute science and no interest in teaching, social service, and the humanities. The issues are raised to the education organizations in sentences (5) and (6) and sentences (7), (8), (9), and (10) provide the proper answer that life needs all kinds of knowledge and wisdom and the education should make people enlightenment and revelation to life. The author holds positive attitude to education: Education is indispensable in our life.

By judging young people's performance, the author states his/her affirmation and praise to education and also emphasizes the educational effect on people. He employs "quality of life is not entirely determined by a balance sheet"in sentence (7), "do more than serve a corporation, a government agency" in sentence (8) and "teaches us to see the connections between things" in sentence (9) and "improve our moral sense" in sentence (10) 
to convey explicitly that education determines the depth and height of life and also promotes dialectical attitude to the relationship of life and job.

Appreciation. Appreciation is performed in terms of either social values or aesthetics. Appreciation resources in the sample text usually include positive or negative assessments of views, objects, events, phenomena, or the states of affairs.

(1) In a time of increasing specialization, more than ever, we need to know what is truly important in life. (positive appreciation of social values)

(2) We have a perspective on the world beyond the confines of our occupation; We want to be able to render service to our fellow men and to our God. (positive appreciation of social values)

(3) How short-sighted in the long run. (negative appreciation of social values)

(4) But he also hosted a classical music show on the college's FM station and listened to Wagner as he studied his accounting. (positive appreciation of social values)

(5) Oscar Wilde had it right when he said we ought to give our ability to our work but our genius to our lives. (positive appreciation of social values)

(6) Let's hope our educators answer students' cries for career education. (positive appreciation of social values)

(7) But at the same time let's ensure that students are prepared for the day when they realize their short-sightedness. (positive appreciation of social values)

Sentences (1) and (2) have active identity and approval to the importance of life and the significance of serving God and society, both of which contain positive appraising resources as "to know what is truly important in life" and "to render service to our fellow men and to our God". The author uses Heterogloss style in sentences (4) and (5) to expand the corpus connotation and increase statements fair and open. The two sentences quote Oscar Wilde's "to give our ability to our work but our genius to our lives" and someone's example "He also hosted a classical music show... as he studied his accounting" to finish his positive appreciation to the idea of "More in life than in job", which makes a contrast with sentence (3). At the end of the passage, the author raises further in sentences (6) and (7) that education can help students experience the nature of life and make life more meaningful and colorful so that the young can come to realize their short-sightedness.

It is obvious that the analysis by Affect, Judgment, and Appreciation subsystems can illustrate the discourse resources more clearly and make the comprehension more distinctly.

\section{Teaching Implication}

The application of Appraisal Theory on the teaching of critical reading is helpful for students to enhance the quality of reading comprehension. Students' integrated reading ability has increased significantly in critical consciousness.

Firstly, the critical reading has brought a new challenge to the traditional reading teaching. The priority of critical reading teaching is to make judgments about how a text is argued and how the central claim is developed. The students must be guided not to read looking only or primarily for information but to read looking for ways of thinking about the subject matter. The teaching should encourage them to ask questions as "How has the author analyzed the materials?" or "How are the evidences (facts or examples) used and interpreted?" instead of "What 
does the sentence mean?" or "What information can I get out of it?". The traditional teaching which focuses on grammar and literal meaning should be transferred to critical reading teaching.

Next, in the teaching process, students' learning initiation, enthusiasm, and desire for something new should be respected and protected. In order to cultivate the learning habit of critical reading, more guideline and instruction are needed from teachers so that students can reduce worries, frustrations, and depression in language acquisition. The teaching process requires the effort of students as well as the work of teachers. Students must learn to accept both reflective thinking and critical analysis. In the activities of presentation, discussion and debate, students' critical reading ability is duly exercised and finally developed.

Lastly, one of the most important tasks in teaching is to improve students reading ability and reflective skill. The teaching practice depicts that the critical reading in Appraisal Theory, is an effective method in English reading teaching. To get the maximum achievement of the teaching strategy, more attention should be paid to the reorientation of teacher roles and reorganization of classroom teaching. By Appraisal systems, teachers and students should get used to the new model of critical reading and accepting the appraisal concept in a new attitude and status.

\section{Conclusion}

The critical reading on Appraisal Theory is a new exploration in College English reading teaching. Appraisal systems are conductive in acknowledging creative positioning, figuring out the effect of choices of language, recognizing the purpose of writing, and understanding underlying values and ideology. Drawing more attention to the critical reading can help learners analyze corpus better from a reflective angle and boost them to get a higher level of reading comprehension in the critical thinking.

\section{References}

Allwright, D., \& Bailey, K. M. (1991). Focus on the spoken language and applied linguistics. Cambridge: Cambridge University Press.

Baker, J., \& Westrup, H. (2000). The English language teacher's handbook. Retrieved from www.vso.org.uk

Davis, P., \& Pearse, E. (2000). Success in English teaching. Oxford: Oxford University Press.

Garrigus, R. (1999). Design in reading: An introduction to critical reading. Bosto: Allyn \& Bacon.

Kasper, L. F. (2000). Content-base college ESL instruction: Theoretical foundation and pedagogical applications. Mahwah, NJ: Lawrence Erlbaum association.

Lightbown, P., \& Spada, N. (2001). Theoretical approaches to explaining second language learning. Oxford: Oxford University Press.

Martin, J. R. (2000). Beyond exchange: Appraisal systems in English, evaluation in text. Oxford: Oxford University Press.

Martin, J. R., \& Rose, D. (2003). Working with discourse: Meaning beyond the clause. London: Continuum Press.

Martin, J. R., \& White, P. R. R. (2005). The language of evaluation: Appraisal in English. London: Continuum Press.

McCarthy, M. (1998). Spoken language and applied linguistics. Cambridge: Cambridge University Press.

Mortimer, J. A., \& Charles, V. D. (1972). The classic guide tointelligent reading. New York: Touchstone Press.

Paul, R. (1995). Critical thinking: How to prepare students for a rapidly changing world. Dillon Beach, CA: Foundation for Critical Thinking. 